ca de imuno-histoquímica. As pacientes foram classificadas em: Grupo A- baixa expressão da proteína p27 (imunorreatividade em padrão nuclear em menos de 50\% das células tumorais) e Grupo B- alta expressão da proteína p27 (imunorreatividade em padrão nuclear em mais de $50 \%$ das células tumorais). A análise estatística foi realizada pelo teste de Goodman com nivel de significância de 5\%. A idade das pacientes variou de 32 a 81 anos. A expressão da proteína p27 foi maior que $50 \%$ em 12 pacientes e menor que 50\% em 39 pacientes. As diferenças quanto ao tamanho do tumor, comprometimento de linfonodos axilares e graduação histológica não apresentaram diferença significante ao se comparar os grupos A e B. Com estes resultados, julgamos ser ainda prematuro utilizar a expressão da proteína p27 como marcador tumoral prognóstico em câncer de mama.

Palavras- Chave: Mama: câncer. Grau histológico. Fatores de prognóstico. Ciclinas.

\title{
Estudo da Infecção Genital por Chlamydia trachomatis em Adolescentes e Jovens do Sexo Feminino no Distrito Sanitário Leste do Municipio de Goiânia: Prevalência e Fatores de Risco.
}

Autora: Rosane Silva Carneiro de Araújo

Orientadora: Profa. Dra. Eleuse Machado de Britto Guimarães

Dissertação apresentada em 14 de novembro de 2001 ao Programa de Pós-graduação em Medicina Tropical do Instituto de Patologia Tropical e Saúde Pública da Universidade Federal de Goiás, para a obtenção do título de Mestre em Medicina Tropical; Área de concentração: Doenças Infecciosas e Parasitárias.

Introdução: A infecção genital por Chlamydia trachomatis é uma das doenças sexualmente transmissíveis mais comuns entre adolescentes e jovens do sexo feminino. As infecções freqüentemente são assintomáticas e as possiveis conseqüências são a doença inflamatória pélvica e a infertilidade. Não existem conhecimentos suficientes sobre a epidemiologia da infecção por C. trachomatis no Brasil, especialmente na região centro-oeste.

Objetivos: Estimar a prevalência da infecção genital pela C. trachomatis em adolescentes e jovens do sexo feminino e identificar os fatores de risco relacionados com infecção cervical por C. trachomatis.

Material e Métodos: A população de estudo consistiu de 296 adolescentes e jovens do sexo feminino: 86 grávidas e 210 não grávidas. O exame ginecológico foi realizado e as amostras laboratoriais obtidas para o exame de amplificação de DNA clamidial (PCR-Amplicor/ Roche). As informações das características sócio-demográficas e de comportamento sexual foram obtidas através de questionário auto-aplicável. A análise estatística foi realizada pelo programa Epi-info (versão 6.0 e versão 2000) e pelo programa SPSS versão 8.0. O valor de $p$ menor que 0,05 foi considerado estatisticamente significante e análise univariada e análise multivariada com regressão logística foram realizadas para detecção dos fatores associados com infecção clamidial.
Resultados: A prevalência geral da infecção clamidial foi de $19,6 \%(58 / 296)$ e $68,9 \%$ das adolescentes e jovens eram assintomáticas. A prevalência em grávidas foi $24,4 \%$ e em não grávidas $17,6 \%$, com p>0,05. A média de idade foi de 18,2 anos (variação de 12 a 24 anos); $51,4 \%$ eram casadas ou viviam em união consensual. $56,1 \%$ apresentavam baixo nivel de escolaridade ( 8 anos ou menos). As mães das adolescentes e jovens tinham menor nivel de escolaridade: $40,5 \%$ (quatro anos ou menos) e destas $8,4 \%$ eram analfabetas. Para 58,1\% das participantes a idade da primeira relação sexual foi 15 anos ou menos; $53,4 \%$ referiam em único parceiro sexual durante toda a vida, mas $15,2 \%$ referiam quatro ou mais parceiros durante toda a vida: $83,1 \%$ referiam um parceiro no último mês. Somente $18,9 \%$ referiam uso de condom em todas as relações sexuais. Treze adolescentes e jovens apresentavam antecedentes de doença sexualmente transmissivel.

Conclusão: A prevalência da infecção genital por $C$. trachomatis nesta população de estudo foi alta. A maioria das participantes estava assintomática. A idade menor que 20 anos e o fato de ter mais que um parceiro sexual foram os fatores de risco relacionados com infecção.

Palavras-chave: Infecção genital. Adolescência. Chlamydia trachomatis. 